\title{
Contribuições para a Formação Inicial de Professores de
}

\author{
Matemática a partir de seu Envolvimento em um Projeto \\ Extensionista Direcionado ao Público Idoso
}

\author{
Contributions to the Mathematics Teacher's Education from the \\ Involvement in a Pedagogical Project Addressed to the Seniors
}

\author{
Nayara da Silva* \\ ORCID iD 0000-0002-2734-8491 \\ Guilherme Henrique Gomes da Silva** \\ ORCID iD 0000-0002-4166-2663 \\ Rejane Siqueira Julio*** \\ ORCID iD 0000-0002-3248-800X
}

\begin{abstract}
Resumo
Neste artigo, discutimos resultados de uma pesquisa que buscou compreender as contribuições para a formação inicial de professores de Matemática quando envolvidos em um projeto de extensão universitária, direcionado ao público idoso. Por meio de uma abordagem qualitativa, utilizamos a metodologia do estudo de caso. Nosso campo de estudo foi constituído pelas ações desenvolvidas durante o ano letivo de 2018 no projeto de extensão Conversas Matemáticas, do Programa Universidade Aberta à Terceira Idade (UNATI) da Universidade Federal de Alfenas (UNIFAL-MG). A equipe do projeto era composta pela pesquisadora, por dois professores coordenadores e três futuras professoras de Matemática. Os dados foram produzidos por meio de registros em caderno de campo, de entrevistas semiestruturadas com as futuras professoras, de relatórios confeccionados durante o projeto e de uma atividade dinâmica de autoavaliação. Os dados foram organizados e analisados utilizando ferramentas da Análise de Conteúdo. Os resultados discutidos neste artigo indicam que o envolvimento das futuras professoras no projeto propiciou contribuições para seu conhecimento pedagógico do conteúdo, pois aprenderam sobre a metodologia de investigação matemática, e conheceram diversas atividades matemáticas, as quais poderão desenvolver em sala de aula. Além disso, os resultados também apontam que o projeto colaborou para que as futuras professoras compreendessem a importância de se construírem boas relações entre os estudantes e o professor, ampliassem sua concepção sobre a Educação Matemática, se familiarizassem com o trabalho pedagógico desenvolvido com públicos de diferentes características e percebessem a relevância de estimular os estudantes a serem sujeitos ativos no desenvolvimento das atividades planejadas.
\end{abstract}

Palavras-chave:. Educação Matemática. Extensão Universitária. Educação de Idosos.

\footnotetext{
* Mestra em Educação pela Universidade Federal de Alfenas (UNIFAL). Docente no Colégio Universitário Machado (UNICOL), Machado, Minas Gerais, Brasil. E-mail: nayarasilva.matematica@gmail.com.

** Doutor em Educação Matemática pela Universidade Estadual Paulista (UNESP). Docente do Instituto de Ciências Exatas e do Programa de Pós-Graduação em Educação da Universidade Federal de Alfenas (UNIFAL), Alfenas, Minas Gerais, Brasil. E-mail: guilherme.silva@unifal-mg.edu.br.

*** Doutora em Educação pela Universidade Estadual de Campinas (UNICAMP). Docente do Instituto de Ciências Exatas e do Programa de Pós-Graduação em Educação da Universidade Federal de Alfenas (UNIFAL), Alfenas, Minas Gerais, Brasil.E-mail: rejane.julio@unifal-mg.edu.br.
} 


\begin{abstract}
This paper discusses the results of a research that sought to understand the contributions to the mathematics teacher's education involved in a project aimed at senior people. A case study methodology through a qualitative approach was used. The research field was constituted by the actions developed during 2018 in the Mathematical Conversations project, from the Open University Program for the Elderly at Federal University of Alfenas (UNIFAL-MG). The project team was composed of the researcher, two coordinating teachers, and three female prospective Mathematics teachers. Data were produced through field notebook records, semi-structured interviews, reports produced during the project, and a dynamic self-assessment activity. Data were organized and analyzed using the Content Analysis tools. Results indicate the involvement of prospective teachers on the project provided contributions to their pedagogical content knowledge, as they learned about the mathematics investigation methodology, and faced several mathematical activities, which they can develop in the classroom. In addition, results also point out that the project collaborated so that prospective teachers understood the importance of building good relationships between students and teachers. They also expanded their conception of Mathematics Education, became familiar with the pedagogical work developed with different audiences, and realized the relevance of encouraging students to be active subjects in the development of planned activities.
\end{abstract}

Keywords: Mathematics Education. University Extension. Elderly Education.

\title{
1 Introdução
}

No cenário brasileiro, a formação de professores de Matemática tem sido um desafio recorrente (OLIVEIRA; FIORENTINI, 2018). As normativas e resoluções atuais orientam que os cursos de Licenciatura devem promover aos futuros professores e professoras uma trajetória acadêmica rica em experiências que ultrapassem os conhecimentos específicos (BRASIL, 2015). Tal trajetória deve fornecer elementos que contribuam para o envolvimento dos futuros professores e professoras com toda a diversidade existente no contexto escolar, incluindo o desenvolvimento de práticas educacionais inclusivas e não discriminatórias, noções de equidade, de justiça social, de diversidade étnico-racial, de gênero, bem como outros aspectos necessários para que possam atuar no sistema educacional (BRASIL, 2015).

$\mathrm{Na}$ literatura brasileira, particularmente relacionada à formação de professores de Matemática, as pesquisas acadêmicas têm abordado um amplo e variado repertório de temáticas. Por exemplo, têm focado na importância do estágio supervisionado no processo de formação inicial (TEIXEIRA; CYRINO, 2015), nas possibilidades de formação a partir da prática como componente curricular (ZABEL; MALHEIROS, 2018) e nos desafios relacionados ao desenvolvimento de experiências em Educação Matemática inclusiva na formação inicial (ROSA, 2013).

Igualmente, as pesquisas têm focado na compreensão da própria estrutura e desenvolvimento dos cursos de Licenciatura em Matemática (BARBOSA; LOPES, 2019), no entendimento de futuros professores e professoras sobre conhecimentos de conteúdos específicos de Matemática (FONSECA; HENRIQUES, 2018), no currículo praticado nos 
cursos de Licenciatura em Matemática (ELIAS; SAVIOLI; RIBEIRO, 2017), nas potencialidades das tecnologias digitais educacionais na futura prática docente (SILVA; PENTEADO, 2013) e nas contribuições do envolvimento de futuros professores e professoras em programas de ensino, como o Programa Institucional de Bolsa de Iniciação à Docência (PIBID) (ALVES, 2017).

Além disso, há pesquisas que retratam as potencialidades de se desenvolverem atividades extensionistas durante a formação inicial de professores de Matemática (BARBOSA, 2018; LOPES; COSTA, 2016; MANDLER et al., 2016; SOUZA, 2016). Tais pesquisas vêm enfatizando, por exemplo, que o envolvimento desses futuros professores e professoras em projetos de extensão pode contribuir em aspectos relacionados ao ganho de experiência na elaboração e no desenvolvimento de atividades pedagógicas com estudantes da Educação Básica.

Entretanto, em relação a essas pesquisas, notamos que os projetos de extensão relatados envolveram futuros professores e professoras em práticas de sala de aula, acompanhando professores ou desenvolvendo atividades pedagógicas no contraturno com estudantes do Ensino Fundamental, Ensino Médio ou Ensino Profissional. Em outras palavras, as ações extensionistas proporcionaram aos licenciandos e licenciandas um contato com espaços onde tradicionalmente ocorre a Educação Básica. Para nós, isso evidencia uma lacuna de pesquisas que retratem as contribuições para a formação inicial de professores e professoras de Matemática inseridos em projetos de extensão que sejam desenvolvidos em outros ambientes que não a escola e que, da mesma forma, envolvam um público diferente daqueles que encontrarão no ambiente escolar. Um exemplo desse público seria a população idosa.

A Educação Matemática tem dado seus primeiros passos no que tange ao trabalho com o público idoso. A ação Conversas sobre Matemática com pessoas idosas, desenvolvida por Lima (2015) no projeto de extensão "Laboratório de Ensino em Educação Matemática”, da Universidade Estadual Paulista (UNESP), campus de Rio Claro-SP, foi pioneira no trabalho com esse público no contexto brasileiro. Nessa ação, Lima (2015) desenvolveu atividades matemáticas que valorizavam o estímulo ao diálogo, ao raciocínio lógico, à criatividade, à intuição e ao desenvolvimento de capacidades cognitivas dos idosos participantes.

Em sua pesquisa, Lima (2015) se propôs a compreender as possíveis contribuições para os idosos que se engajavam nestas atividades matemáticas, as quais eram planejadas por ele e por uma equipe de futuros professores e professoras de Matemática e de Pedagogia. Lima (2015) constatou que o engajamento dos idosos no projeto contribuiu para o 
desenvolvimento de suas capacidades cognitivas, a melhora na concentração, na recordação de conteúdos matemáticos e no raciocínio lógico. Por mais que não fosse o seu objetivo de pesquisa, Lima (2015) apontou que o projeto também trouxe contribuições importantes para os futuros professores e professoras envolvidos, uma vez que ofereceu subsídios para que se tornassem profissionais mais abertos a aprender e a valorizar os conhecimentos do ser humano e a desenvolver um senso de paciência e compreensão. Isso proporcionou a abertura para um campo importante no âmbito da pesquisa em Educação Matemática. Essa abertura e a carência de trabalhos nessa temática nos inspiraram no desenvolvimento de nossa pesquisa, discutida neste artigo, cujo objetivo foi compreender as contribuições para a formação inicial de professores de Matemática quando envolvidos em um projeto de extensão universitária direcionado ao público idoso.

\section{Conhecimentos do professor que ensina Matemática}

No âmbito da formação de professores, muitos trabalhos têm discutido sobre os conhecimentos necessários para o exercício da docência (BALL; THAMES; PHELPS, 2008; MIZUKAMI, 2004; RIBEIRO, 2016; SHULMAN, 2014). Lee S. Shulman foi um dos precursores e uma referência importante na literatura relacionada a essa temática. Ele determinou um repertório de conhecimentos para o ensino, constituído pelas categorias: conhecimento do conteúdo; conhecimento pedagógico geral; conhecimento do currículo; conhecimento pedagógico do conteúdo; conhecimento dos alunos e de suas características; conhecimento dos contextos educacionais; conhecimento dos fins, propósitos e valores da educação e de sua base histórica e filosófica (SHULMAN, 2014).

Diversos trabalhos têm se inspirado em Shulman e discutido/adaptado/aprimorado/criticado as ideias do autor no que tange aos conhecimentos considerados importantes para o exercício da docência. Por exemplo, Mizukami (2004) apresenta um agrupamento das categorias de Shulman (2014) da seguinte forma: conhecimento do conteúdo específico, conhecimento pedagógico do conteúdo e conhecimento pedagógico geral. O conhecimento do conteúdo específico refere-se ao conhecimento dos conteúdos da disciplina que o professor leciona (MIZUKAMI, 2004). Este conhecimento mobiliza a compreensão dos elementos básicos da disciplina trabalhada por professores e professoras e das variadas formas de representá-los. Em sua representação, docentes buscam considerar o contexto em que estão ensinando, bem como o público que compõe sua sala de aula. 
O conhecimento pedagógico do conteúdo corresponde a uma combinação entre o conteúdo específico e a pedagogia na compreensão da forma como os conteúdos, os problemas ou as questões podem ser organizados, representados e adaptados, para que possam ser levados para sala de aula, visando atingir os diferentes interesses dos estudantes e os objetivos educacionais (SHULMAN, 2014). Por sua vez, o conhecimento pedagógico geral, segundo Mizukami (2004), vai além de uma área específica, sendo que este envolve conhecer teorias relacionadas com o processo de ensino e de aprendizagem, contextos educacionais, características dos estudantes, outras disciplinas que podem colaborar com o entendimento de conteúdos de sua área específica, entre outros elementos.

No âmbito da formação de professores de Matemática, Deborah Ball e seus colaboradores de pesquisa têm se baseado nos trabalhos de Shulman. Ball, Thames e Phelps (2008), com foco exclusivamente nos conhecimentos relacionados ao professor que ensina Matemática, apresentaram uma divisão do conhecimento do conteúdo e do conhecimento pedagógico do conteúdo (Figura 1).

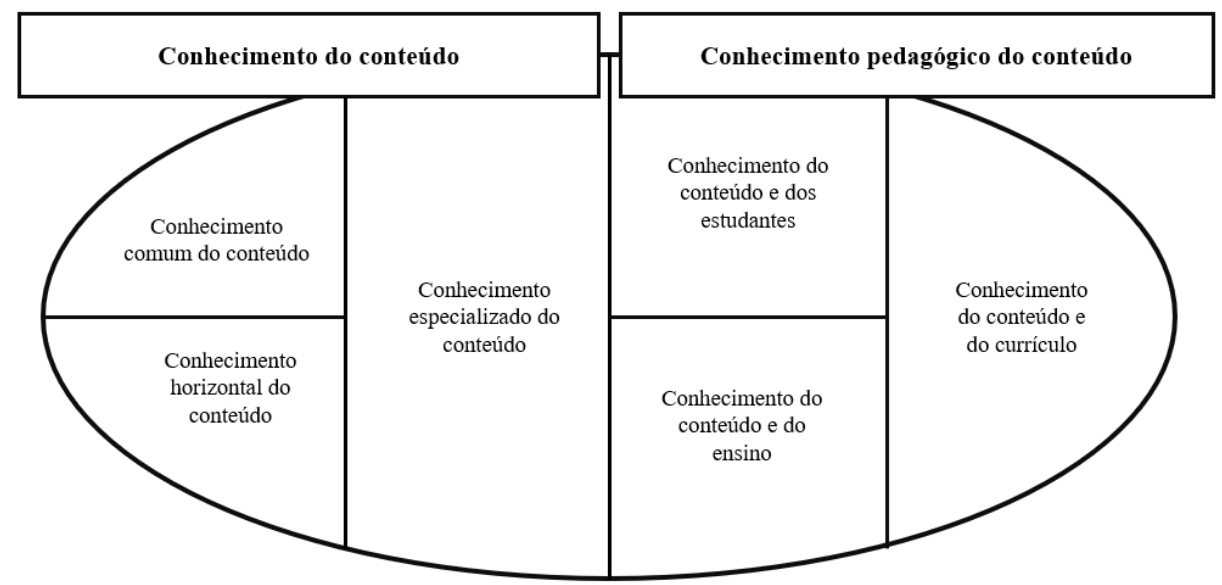

Figura 1 - Divisão dos conhecimentos necessários para o ensino.

Fonte: Figura adaptada do artigo de Ball, Thames e Phelps (2008, p. 403, com tradução livre)

Ball, Thames e Phelps (2008) dividiram o conhecimento do conteúdo em conhecimento comum do conteúdo, conhecimento especializado do conteúdo e conhecimento horizontal do conteúdo. O conhecimento comum do conteúdo, segundo Ribeiro (2016), é mobilizado pelo professor, e por profissionais de outras áreas, como engenheiros e físicos. Este conhecimento não é exclusivo para o ensino, pois pode ser utilizado em diversos contextos profissionais. O conhecimento especializado do conteúdo corresponde ao conhecimento matemático e às habilidades próprias para o ensino, permitindo que professores tratem de atividades destinadas apenas ao ensino; algumas delas correspondem à busca de representações matemáticas em determinadas situações e à apresentação de explicações com base em regras e procedimentos matemáticos (RIBEIRO, 2016). O conhecimento horizontal 
do conteúdo refere-se ao processo de reflexão do professor em relação à forma como a Matemática que está sendo trabalhada em um determinado momento de sua prática se relaciona com a Matemática que será trabalhada com os mesmos estudantes nas etapas posteriores de escolarização. Este conhecimento permite aos professores e professoras estabelecerem a fundamentação matemática necessária para o estudante em períodos futuros (RIBEIRO, 2016).

Já o conhecimento pedagógico do conteúdo foi dividido em: conhecimento do conteúdo e dos estudantes; conhecimento do conteúdo e do ensino; e conhecimento do conteúdo e do currículo. O conhecimento do conteúdo e dos estudantes corresponde a uma combinação entre o conhecimento matemático e o conhecimento sobre os estudantes. Este conhecimento permite ao professor compreender os possíveis erros e as dificuldades que os estudantes podem ter com determinado conteúdo (RIBEIRO, 2016). É um conhecimento que também possibilita que o professor saiba analisar se os exemplos selecionados para o ensino serão considerados interessantes pelos estudantes, que ele saiba o que os estudantes irão achar do conteúdo que será explorado e que ele já tenha ideia das estratégias que os estudantes utilizarão na resolução das atividades selecionadas (BALL; THAMES; PHELPS, 2008).

O conhecimento do conteúdo e do ensino possibilita que docentes, ao selecionarem o conteúdo a ser trabalhado, escolham um conjunto de exemplos com que se iniciará o conteúdo e que será utilizado para aprofundar tal assunto, como também possam analisar as vantagens e desvantagens de se adotar uma determinada representação de ideias, buscando selecionar metodologias de ensino que favoreçam a construção do conhecimento pelos estudantes. Essas tarefas exigem uma relação entre o conhecimento do conteúdo e o conhecimento de assuntos pedagógicos que interferem no aprendizado do estudante. Por fim, o conhecimento do conteúdo e do currículo refere-se a conhecer "diretrizes curriculares, orientações, fins e motivações das mesmas, materiais curriculares e sequencialização dos temas nos diferentes níveis escolares" (RIBEIRO, 2016, p. 54). Notamos que Ball e seus colaboradores de pesquisa compreendem as particularidades da docência no âmbito da Educação Matemática e destacam elementos que nos auxiliaram no desenvolvimento deste estudo.

\section{Metodologia}

Para compreender as contribuições para a formação inicial de professores e professoras de Matemática envolvidos em um projeto de extensão direcionado ao público idoso, realizamos uma pesquisa de abordagem qualitativa utilizando a metodologia do estudo 
de caso (CRESWELL, 2014). O campo de pesquisa deste estudo foi constituído pelas ações realizadas no ano de 2018 no projeto de extensão Conversas Matemáticas, inserido no Programa Universidade Aberta à Terceira Idade (UNATI) da Universidade Federal de Alfenas (UNIFAL-MG). Por meio de atividades investigativas, lúdicas e de construção e manipulação de materiais, este projeto busca promover a Educação Matemática com pessoas idosas (JULIO; SILVA, 2019a). Na versão 2018 do projeto, foram realizadas 27 atividades, a maior parte delas convidando as idosas participantes ${ }^{1}$ a se engajarem em cenários para investigação (SKOVSMOSE, 2000). Algumas atividades trabalharam com processos investigativos articulados com a História da Matemática, outras relacionaram a Matemática com a arte, houve aquelas que trabalharam com a Matemática utilizada pelas idosas em seu cotidiano, como também as que se voltaram para a confecção de materiais, com o intuito de discutir conteúdos matemáticos. No Quadro 1, apresentamos todas as atividades realizadas em 2018 no projeto.

\begin{tabular}{|c|c|c|c|}
\hline Encontro & Atividade realizada & Encontro & Atividade realizada \\
\hline $\mathbf{0 1}$ & Tangram & $\mathbf{1 5}$ & Tangram Oval - Confeç̧ão \\
\hline $\mathbf{0 2}$ & Jogo do Quarto & $\mathbf{1 6}$ & Tangram Oval \\
\hline $\mathbf{0 3}$ & Quadrados Mágicos & $\mathbf{1 7}$ & Desafio com palitos \\
\hline $\mathbf{0 4}$ & Razão Áurea & $\mathbf{1 8}$ & Faixa de Mobius \\
\hline $\mathbf{0 5}$ & Torre de Hanói & $\mathbf{1 9}$ & Quadriláteros \\
\hline $\mathbf{0 6}$ & Origami - Tsuru & $\mathbf{2 0}$ & Compras no "supermercado" \\
\hline $\mathbf{0 7}$ & Dominó das Quatro Cores & $\mathbf{2 1}$ & Fractais \\
\hline $\mathbf{0 8}$ & Jogo Rummikub - Confecção & $\mathbf{2 2}$ & Jogo da Onça e do Cachorro \\
\hline $\mathbf{0 9}$ & Jogo Rummikub & $\mathbf{2 3}$ & Barra de Cuisenaire \\
\hline $\mathbf{1 0}$ & Dominó das 4 Cores - Confecção & $\mathbf{2 4}$ & Molde de Roupa \\
\hline $\mathbf{1 1}$ & Sequência de Fibonacci & $\mathbf{2 5}$ & Dia de Jogos variados \\
\hline $\mathbf{1 2}$ & Compras na Internet & $\mathbf{2 6}$ & Dinâmica de autoavaliação \\
\hline $\mathbf{1 3}$ & Jogo Contig 60 & $\mathbf{2 7}$ & Bingo matemático \\
\hline $\mathbf{1 4}$ & Sudoku e Kakuro & & \\
\hline
\end{tabular}

Quadro 1 - Atividades realizadas no projeto de extensão Conversas Matemáticas

Fonte: Os autores (2018)

A equipe da versão 2018 do projeto foi formada pela pesquisadora (primeira autora deste artigo), dois professores coordenadores (demais autores do artigo, orientador e coorientadora da pesquisa) e três futuras professoras de Matemática, chamadas neste texto de Alana, Eduarda e Laura (nomes fictícios). Alana, estudante do segundo ano de graduação, já havia sido voluntária em outro projeto de extensão, o qual atendia crianças de um semiabrigo, e, durante sua participação no projeto Conversas Matemáticas, também foi bolsista do PIBID-

${ }^{1} \mathrm{O}$ projeto Conversas Matemáticas está inserido no Programa Universidade Aberta à Terceira Idade (UNATI) da Universidade Federal de Alfenas (UNIFAL-MG), o que faz com que suas atividades sejam direcionadas aos idosos que participam deste programa. Antes de iniciar o desenvolvimento do projeto, realizamos a sua divulgação para todos os participantes do programa e estabelecemos um período para que os idosos e as idosas que se interessassem em participar do projeto realizassem sua inscrição. Após esse período, o grupo de participantes foi constituído apenas por mulheres idosas. 
Matemática. Eduarda e Laura estavam cursando o último ano da graduação e também já haviam participado do PIBID-Matemática em anos anteriores.

A equipe do projeto se reunia semanalmente para elaborar e discutir as atividades matemáticas a serem desenvolvidas no mesmo. Para isso, as futuras professoras estudaram teóricos da Educação Matemática, como Skovsmose (2000), Ponte, Brocardo e Oliveira (2006) e Silva e Penteado (2013), que contribuíram para seu aprofundamento no desenvolvimento de atividades investigativas, e Lima (2015), com quem conheceram maneiras de se desenvolverem atividades matemáticas com o público idoso. Elas também consultavam relatos de experiência, artigos, livros, entre outros materiais, que colaboravam no planejamento das atividades do projeto. Realizavam ainda encontros fora do horário das reuniões de planejamento, para que pudessem estudar conteúdos matemáticos necessários para as atividades e explorar as próprias atividades elaboradas, visando encontrar erros ou antecipar momentos que poderiam gerar situações inusitadas ou inesperadas. Para o desenvolvimento das atividades planejadas, foram realizados encontros com as idosas, que ocorriam semanalmente no Laboratório de Ensino de Matemática da Universidade Federal de Alfenas (UNIFAL-MG) e tinham duas horas de duração, participando uma média de oito idosas por encontro.

Utilizando a observação participante (LUDKE; ANDRÉ, 1986), os dados deste estudo foram produzidos a partir dos encontros desenvolvidos com as idosas participantes do projeto e também durante todas as reuniões de planejamento da equipe. Nos encontros com as idosas, a pesquisadora auxiliava as futuras professoras e as participantes, porém, na maioria do tempo, apenas realizava observações. Ao término de cada encontro, as bolsistas escreviam, em conjunto, um relatório para descrever detalhadamente a maneira como ocorrera o desenvolvimento da atividade. A pesquisadora acompanhava a elaboração dos relatórios, realizando apenas observações. A reunião de planejamento da equipe do projeto se organizava em dois momentos: no primeiro, com base no relatório confeccionado pelas futuras professoras, a equipe discutia a atividade desenvolvida naquela semana, o que consequentemente resultava na reelaboração do relatório de acordo com as discussões; no segundo momento, a equipe realizava o planejamento da atividade que seria desenvolvida na semana seguinte. Durante as reuniões, a pesquisadora atuava apenas como observadora. Todos os dados produzidos nas observações foram registrados em caderno de campo.

Ainda, no final de 2018, foram realizadas entrevistas semiestruturadas com as futuras professoras. No decorrer do projeto, cada bolsista passou por experiências marcantes e buscamos, através das entrevistas, conhecer com mais profundidade tais experiências. Por 
isso, os três instrumentos de entrevistas semiestruturadas que elaboramos não foram iguais, embora, em alguns momentos, tivessem perguntas semelhantes. As entrevistas foram gravadas em áudio e posteriormente transcritas. Ademais, em um dos encontros do projeto, foi realizada uma dinâmica de autoavaliação com as idosas, da qual também participou a equipe executora (JULIO; SILVA, 2019b). Esta atividade foi gravada em áudio, para que as falas das futuras professoras fossem transcritas, de modo a compor os dados da pesquisa.

Para organizar e analisar os dados, utilizamos as ferramentas da Análise de Conteúdo (BARDIN, 2016) e tivemos auxílio do software ATLAS.ti. Segundo Bardin (2016), a Análise de Conteúdo possui três fases: pré-análise; exploração do material; e tratamento dos resultados, inferência e interpretação. Na primeira fase, foi realizada a organização dos dados, com o intuito de formar o corpus da pesquisa, ou seja, de selecionar os documentos que seriam analisados. Este foi constituído por registros no caderno de campo, relatórios confeccionados pelas futuras professoras e reelaborados nas reuniões, transcrições das entrevistas semiestruturadas e transcrições das falas das futuras professoras durante a dinâmica de autoavaliação.

A segunda fase consistiu na exploração do material que formou o corpus da pesquisa. Nesta fase, determinamos vários temas, formados por unidades de registro, que correspondem aos recortes de partes importantes dos documentos analisados e que expressam uma mesma ideia. Posteriormente, agrupamos tais temas com base em suas semelhanças e diferenças, para construirmos os eixos temáticos. Para finalizar, agrupamos os eixos temáticos com base em suas características em comum, estabelecendo categorias de análise. Após essa construção, desenvolvemos a terceira fase, que diz respeito ao tratamento dos resultados obtidos e sua interpretação. Nesta fase, discutimos os dados com base no referencial teórico adotado para a pesquisa. Neste estudo, visando compreender as contribuições do projeto de extensão Conversas Matemáticas para a formação das futuras professoras de Matemática, discutiremos duas categorias de análise, as quais foram denominadas de investigação matemática enquanto metodologia de ensino e Educação Matemática com pessoas idosas.

\section{Investigação matemática enquanto metodologia de ensino}

Nesta seção, discutimos resultados que indicam que o envolvimento das futuras professoras de Matemática no projeto de extensão Conversas Matemáticas contribuiu para o seu conhecimento pedagógico do conteúdo, mais especificamente para o conhecimento do conteúdo e do ensino (BALL; THAMES; PHELPS, 2008), visto que se engajaram na 
construção de atividades pedagógicas de caráter investigativo, aprendendo, dessa forma, a trabalhar com uma metodologia de ensino voltada à investigação matemática, em particular a criação de cenários para investigação.

Skovsmose (2000) destaca a existência de, pelo menos, duas práticas no ensino de Matemática: cenários para investigação e paradigma do exercício. Diferentemente da bateria de exercícios do paradigma do exercício, característica no ensino tradicional de Matemática, em que a estrada costuma ser segura e previsível no terreno, cenários para investigação costumam possuir trilhas não tão bem demarcadas, o que possibilita momentos de abertura de possibilidades aos estudantes (SKOVSMOSE, 2014).

Nesse sentido, cenários para investigação são ambientes de aprendizagem que oferecem suporte a um trabalho de investigação matemática, em que o estudante é convidado a formular questões e a procurar explicações. O convite geralmente é caracterizado por questionamentos do professor do tipo "o que acontece se...?". Já o estudante indica que aceitou o convite por meio de reflexões do tipo "sim, o que acontece se...?". Ao convidar o estudante, o professor não tem a certeza de que o convite será aceito, pois o estudante pode ou não voltar sua intencionalidade ao tema.

Segundo Skovsmose (2000), há pelo menos três tipos de referência em atividades realizadas, tanto no paradigma do exercício quanto em cenários para investigação: "Matemática", que corresponde às atividades que focam exclusivamente na Matemática em si; "Semirrealidade", que se refere ao desenvolvimento de atividades em uma realidade construída; e "Realidade", que se refere ao trabalho com situações reais, com dados verdadeiros ou em ambientes reais da vida cotidiana. Ao combinarmos as referências com as duas práticas de ensino, obtemos seis ambientes de aprendizagem (Quadro 2).

\begin{tabular}{|c|c|c|}
\hline Dimensão/Tamanho & Paradigma do exercício & Cenários para investigação \\
\hline Referências à Matemática & $(1)$ & $(2)$ \\
\hline Referências a uma semirrealidade & $(3)$ & $(4)$ \\
\hline Referências à vida real & $(5)$ & $(6)$ \\
\hline
\end{tabular}

Quadro 2 - Ambientes de aprendizagem

Fonte: Adaptado de Skovsmose (2014, p. 54)

No ambiente (1), predominam atividades imperativas do tipo "calcule", "resolva", "encontre o valor do x"; no ambiente (2), as atividades desenvolvidas convidam os estudantes a investigarem propriedades matemáticas. No ambiente (3), as atividades construídas visam exclusivamente à resolução do exercício; no ambiente (4), situações pedagógicas em uma semirrealidade são usadas como um espaço para investigação. No ambiente (5), mesmo utilizando de informações e dados reais, o foco continua sendo na aplicação de técnicas matemáticas para a resolução do exercício; já no ambiente (6), uma investigação em uma 
situação real é conduzida pelos estudantes, buscando muitas vezes compreender e até mesmo modificar tal situação.

Segundo Ponte, Brocardo e Oliveira (2006), o uso de investigações matemáticas enquanto metodologia de ensino e de aprendizagem propicia aos estudantes a compreensão da Matemática como uma construção humana, uma vez que podem formular questões e conjecturas, realizar provas e refutações e também apresentar e discutir os resultados encontrados durante o processo investigativo. Estes autores oferecem orientações importantes para a prática docente relacionada ao uso da metodologia de investigação matemática, principalmente para atividades desenvolvidas no ambiente (2), que fazem referência à Matemática em si, ambiente no qual predominaram muitas das atividades desenvolvidas no projeto.

As futuras professoras envolvidas no projeto Conversas Matemáticas destacaram que, durante sua participação no PIBID-Matemática, haviam desenvolvido algumas atividades pedagógicas que buscavam, de alguma forma, propiciar mais engajamento dos estudantes. Porém, através do projeto, enfatizaram que puderam vivenciar novas experiências e, de fato, compreender e se aprofundar no trabalho com investigações matemáticas em sala de aula, relacionando os estudos teóricos realizados para o planejamento das atividades com seu desenvolvimento na prática docente com as idosas. A fala de Laura, por exemplo, resume o sentimento apresentado pelas futuras professoras sobre essa questão:

Eu acho que foi uma metodologia que eu não conhecia, já vi todo um estudo teórico, já houve algumas tentativas dentro da sala de aula, só que ainda assim não houve uma experiência. Então, eu acho que o projeto, ele fez a gente reforçar muito isso, sabe? Porque, como que eu posso falar? Eu acho que o projeto nos fez ter uma melhor experiência. Não ter uma melhor experiência, mas ter mais experiência. Senti de verdade como que é, pois muitas vezes a gente levava na sala [de aula] e os alunos não aceitavam o convite. Então, ali com as idosas a gente teve um outro ponto de vista, olha, realmente funciona. Tanto é que, no PIBID mesmo, eu não conhecia essa metodologia investigativa, só que ainda assim a gente tentava fazer algumas coisas, mesmo a gente não tendo o teórico ali, algumas coisas eram feitas. Claro que nem tudo era sucesso, mas havia uma tentativa. Só que, com o projeto e com a fundamentação teórica que foi vista pelos estágios, eu acho que contribuiu mais, a gente pôde ter uma melhor experiência em relação à prática. Tanto é que algumas atividades que aconteceram eu poderia inserir dentro da sala de aula, que para mim foi vista completamente diferente (Transcrição da entrevista com Laura, 2018).

As futuras professoras evidenciaram, em seus relatos, que suas experiências com a metodologia de ensino de investigação matemática no projeto de extensão oportunizaram a elas vivências que permitiram uma relação de proximidade entre a teoria e a prática pedagógica. Laura, por exemplo, destacou que aprendeu sobre a metodologia de ensino de investigação matemática durante seu estágio supervisionado e trabalhou com ela no projeto de 
extensão, na perspectiva da criação de cenários para investigação, na qual a vemos utilizar, inclusive, o termo "aceitavam o convite", de forma coerente com esta perspectiva. Compreendemos que seu envolvimento no projeto pode ter colaborado para que Laura entendesse a importância da proximidade entre a teoria e a prática durante o desenvolvimento de atividades investigativas. Isso vai ao encontro das ideias de Silva, Penha e Gonçalves (2017), que consideram ações extensionistas como uma possibilidade de aproximação da teoria estudada nas disciplinas dos cursos de Licenciatura com a prática pedagógica.

No desenvolvimento de atividades investigativas em sala de aula, Alrø e Skovsmose (2010) apontam para a importância do diálogo, de modo que o professor possa estimular os estudantes a pensarem criticamente e a refletirem sobre a situação trabalhada. A descrição dos relatórios elaborados pelas futuras professoras, bem como sua prática durante o desenvolvimento das atividades do projeto, nos revelam indícios de que estavam atentas a isso, como pode ser visto no trecho a seguir, retirado de um dos relatórios:

Para o passo dois, de dividir a circunferência em quatro partes iguais, houve uma discussão sobre ângulo, pois a idosa Aparecida estava um pouco perdida. A bolsista Eduarda propôs que as idosas tentassem fazer a divisão e percebeu que elas ficaram esperando a resposta. Carla disse: "estou esperando você dizer". Então Eduarda devolveu a pergunta: "eu gostaria que vocês tentassem", e isso gerou diversas discussões (Relatório confeccionado pelas bolsistas na atividade Tangram Oval, 2018).

$\mathrm{Na}$ atividade destacada no relatório, foi proposto às idosas participantes do projeto que que confeccionassem individualmente o seu próprio Tangram Oval, para que, durante a sua construção, as futuras professoras pudessem discutir com as participantes sobre os materiais que poderiam ser utilizados, as estratégias de construção e os elementos da circunferência, como o raio, o setor, a corda, o segmento circular e o diâmetro.

O relato contido no relatório evidencia que as futuras professoras não apresentaram respostas de imediato às perguntas das idosas, mas as devolveram com comentários, de modo a estimular as participantes a refletirem sobre os pontos levantados durante a atividade, gerando diálogos. Situações semelhantes à que foi descrita também ocorreram em outras atividades.

Consideramos que o comportamento das futuras professoras durante $\mathrm{o}$ desenvolvimento das atividades vai ao encontro, também, do que Ponte, Brocardo e Oliveira (2006) afirmam a respeito da condução de uma atividade investigativa. Segundo os autores, nessa condução, a postura do professor passa a ser mais interrogativa do que imperativa. Neste sentido, quando os estudantes colocam alguma questão, o professor pode devolvê-la 
com possíveis pistas ou mesmo perguntando de outra maneira, mas sempre buscando fazer com que os estudantes pensem melhor sobre o questionamento.

De acordo com Skovsmose (2014), é importante que o processo educacional seja conduzido como uma viagem pelos seis ambientes de aprendizagem destacados no Quadro 2. Por exemplo, o professor pode iniciar uma atividade no ambiente (2) e posteriormente conduzir sua turma a realizar exercícios no ambiente (1), para aprimorarem alguma técnica matemática. Em seguida, o professor pode convidar os estudantes a investigarem uma situação no ambiente (4), no qual o uso de tais técnicas pode ser essencial.

Esse "caminhar" por diferentes ambientes de aprendizagem foi realizado em diversas atividades do projeto Conversas Matemáticas. Por exemplo, na atividade Fractais, as futuras professoras, com o intuito de iniciar no ambiente de aprendizagem (2), deram abertura para que as idosas, em conjunto, montassem as quatro primeiras iterações do Triângulo de Sierpinski (Figura 2). A cada iteração, as idosas investigavam o que havia acontecido com a quantidade de triângulos e com o comprimento do lado de cada um. Ao finalizar as quatro iterações, as futuras professoras passaram a discutir com as idosas como elas poderiam expressar matematicamente, em cada iteração, o crescimento no número de triângulos e as mudanças no comprimento de cada lado dos triângulos. Tal sistematização matemática foi realizada, pois as futuras professoras visavam obter, juntamente com as idosas, uma fórmula que generalizasse a quantidade de triângulos e o comprimento de cada um de seus lados, em cada iteração. Por meio desta fórmula, as futuras professoras discutiram com as idosas o significado de uma função exponencial.

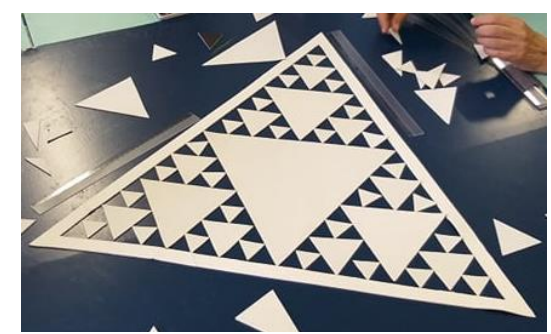

Figura 2 - Construção final das primeiras iterações do Triângulo de Sierpinski Fonte: Os autores (2018)

Para finalizar, as futuras professoras conduziram a atividade para o ambiente de aprendizagem (1), pois solicitaram que as idosas resolvessem alguns exercícios que retratavam iterações no Triângulo de Sierpinski, para aprimorarem a técnica matemática. As experiências associadas a esse "caminhar" pelos diferentes ambientes de aprendizagem marcaram as futuras professoras. Por exemplo, Alana apresentou uma reflexão que demonstra o seu aprendizado em relação às suas experiências:

Às vezes eu acho que é preciso de um dia do paradigma do exercício, eu acho que precisa. Eu 
não sei se é porque eu já fiz muito desse estilo ao longo dos anos, mas, assim, eu não vejo dos males o pior. Claro que, se ficar só nele, né, supercansativo, não dá. Mas eu acho que é necessário. Então, quando o professor [coordenador do PIBID] pede de forma investigativa, eu uso muito o projeto, que foi basicamente tudo investigativo, é a intenção do projeto. Quando é algo mais técnico, eu tento pensar como seria ter uma porcentagem de investigação, mesmo técnico, não precisa parecer que é investigativo, mas que tenha uma perguntinha lá, por exemplo, uma resolução de problemas, não deixa de ser um exercício proposto. Uma perguntinha lá na resolução de problemas que dá um arzinho de investigação, entendeu? Acho que é isso, ter uma pitadinha de investigação, eu tento porque eu acho importante (Transcrição da entrevista com Alana, 2018).

Como já mencionamos, a maior parte das atividades propostas para os encontros do projeto convidava as idosas a se envolverem com investigações matemáticas. Dessa forma, temos indícios de que as experiências vivenciadas pelas futuras professoras durante o desenvolvimento dessas atividades podem ter contribuído para sua motivação em utilizar essa metodologia no PIBID-Matemática, como ocorreu com Alana, e em sua futura prática docente. Isso também pode ser exemplificado pelos recortes das entrevistas com Eduarda e Laura:

Então eu já tinha tentado levar, né [investigação matemática na sala de aula], aí não deu tanto certo. Então eu estava meio desmotivada de levar, mas eu acho que eu ia tentar levar sim, mesmo que não tivesse participado do projeto. Ainda nunca tive uma experiência de ter uma turma que é só minha e tal, talvez eu pudesse conseguir utilizar, mas o projeto me motivou bem mais a tentar levar [para sala de aula] (Transcrição da entrevista com Eduarda, 2018).

Eles [estudantes da Educação Básica] já estão habituados em receber respostas. Então, eu acho que, quando chega, é um baque, então eu acho que vale a pena tentar inserir a investigação. Acho que o projeto me fez mudar completamente a minha visão nesse sentido, porque eu via a investigação só que muitas vezes assim, não por não ver a importância, mas muitas vezes eu ficava um pouco desanimada. Mas eu acho que, com o projeto, com os resultados, a gente vê que vale a pena. Então, acho que eu tentaria sim, por mais que tivesse que cumprir toda uma ementa, acho que vale a pena, é importante. Pelo menos uma vez ou outra, os alunos têm que conhecer o outro lado. E sem falar que a gente está sendo preparado para isso, para ter mudança mesmo, né? (Transcrição da entrevista com Laura, 2018).

Laura demonstrou ter reconhecido a importância de se trabalhar com a metodologia de investigação matemática em sala de aula. Contudo, indicou uma preocupação com a ementa curricular, principalmente no contexto escolar, onde geralmente professores são pressionados a "dar conta" de uma grande quantidade de conteúdos no ano letivo. Segundo Ponte (2003), professores consideram que trabalhar com os temas constituintes do currículo obrigatório da disciplina de Matemática é uma responsabilidade prioritária e muitos encaram as atividades de investigação como algo que pode "atrasar" o trabalho com os conteúdos que formam a ementa da disciplina. A preocupação de Laura com os conteúdos, quando diz que tentará utilizar o que aprendeu no projeto, "por mais que tivesse que cumprir toda uma ementa", 
mostra que, mesmo vivenciando resultados interessantes nas atividades do projeto, o cumprimento da ementa ainda está fortemente ligado a um padrão de aulas mais pautado no paradigma do exercício.

Nossa análise dos dados também traz indícios de que o fato de as futuras professoras experienciarem a utilização da metodologia de investigação matemática no desenvolvimento das atividades do projeto favoreceu a criação de um sentimento de confiança em relação ao preparo e ao desenvolvimento de atividades investigativas. Por exemplo, Eduarda indicou ter adquirido segurança no uso dessa metodologia em sua prática docente, sentindo-se preparada para utilizá-la em outros ambientes educacionais:

Eu já tinha tentado utilizar na escola [PIBID e estágio supervisionado], mas eu acho que hoje em dia eu estou bem mais segura para utilizar [investigação matemática], pela questão da prática e pela questão do estudo teórico que eu tive. Então com certeza eu levaria [para sala de aula], eu acho que contribui bastante para a aprendizagem (Transcrição da entrevista com Eduarda, 2018).

Para nós, a fala de Eduarda pode indicar que ela se sente preparada para explorar a metodologia investigativa em sala de aula. Isso vai ao encontro do que Ponte (2003) afirma, quando destaca que experiências positivas com atividades de investigação promovem a autoconfiança para trabalhar neste campo. Consideramos que as experiências vivenciadas pelas futuras professoras com esta metodologia foram positivas, uma vez que destacaram, em diversos momentos, que as idosas participavam ativamente do processo de investigação nas atividades.

Durante as atividades desenvolvidas no projeto, em vários momentos, as futuras professoras vivenciaram situações que não haviam previsto durante o planejamento das atividades investigativas. Isso é comum em atividades com essa abordagem (SKOVSMOSE, 2014). Muitas vezes, atividades investigativas podem levar professores e professoras a sair de uma zona de conforto, caracterizada pela previsão e controle da situação, e se ver em uma zona de risco, em que é necessário refletir a todo o momento a respeito das decisões a serem tomadas (PENTEADO, 2001). Neste sentido, o professor, ao trabalhar com atividades investigativas, pode se deparar com desafios não previstos na etapa de planejamento, necessitando, muitas vezes, tomar decisões sobre situações que nunca vivenciou (SILVA; PENTEADO, 2013)

As futuras professoras vivenciaram tais situações em alguns momentos durante o desenvolvimento das atividades realizadas no projeto, desviando-se do planejamento estabelecido. Por exemplo, na atividade Compras na Internet, a equipe do projeto estabeleceu que as idosas deveriam escolher um produto dentre alguns listados, para poder realizar uma 
simulação de compra em diferentes websites. A atividade buscava criar um cenário para investigação, para que as idosas analisassem variadas formas de pagamento que poderiam ser utilizadas em compras pela internet, suas vantagens e desvantagens e também o impacto no preço final do produto causado pelo valor do frete de entrega.

$\mathrm{Na}$ preparação da atividade, as futuras professoras testaram alguns websites e escolheram a lista de produtos que as idosas analisariam para selecionar o produto a "ser comprado". Entretanto, no desenvolvimento da atividade, as idosas não aceitaram os produtos propostos e escolheram outro. No momento em que foi realizada a primeira simulação de compra, notou-se que o produto selecionado fornecia frete grátis. Tal situação, aparentemente simples, deixou Alana em uma zona de risco, uma vez que grande parte da discussão que ela havia planejado para conduzir com as idosas se pautava no impacto do valor do frete no preço final do produto. Ao refletir sobre essa situação, Alana colocou sua experiência com o imprevisto da seguinte forma:

Um produto que a gente [idosas e bolsistas] começou a ver que era um celular, eu acho, ou era um livro. Um livro, e não tinha frete, e o que eu tinha planejado é que tivesse frete para a gente poder calcular o frete, as diferenças do frete, a diferença de quando é à vista, com o frete, quando é a prazo, quando é com o cartão da loja, e aí, o que a gente decidiu fazer era tudo frete grátis, então não teve um a mais que poderia ser analisado, que era o frete. Então, a gente tinha aquela tabela e o espaço do frete ficou tudo zerado, eu acho que foi uma perda para aplicação da atividade (Transcrição da Entrevista com Alana, 2018).

Alana, em seu relato, demonstra frustração com a experiência de zona de risco que vivenciou, pois não teve reação, ou seja, ela se mostrou paralisada, sem saber o que fazer. Esta foi uma experiência que colaborou para que Alana refletisse sobre como é estar no ambiente de imprevisibilidade e como o professor pode agir ao se deparar com situações em que a atividade se direciona para um caminho diferente do planejado.

Além disso, conforme as futuras professoras foram vivenciando experiências com a zona de risco durante o desenvolvimento do projeto, elas demonstraram ter compreendido a importância de usufruir do potencial de uma situação de imprevisibilidade. Por exemplo, na atividade Desafio com Palitos, foi proposto que as idosas trabalhassem com desafios em que tinham uma forma geométrica modelada por palitos e deveriam modificar as posições de uma determinada quantidade deles, para formar outra forma geométrica. O Quadro 3 refere-se a um dos desafios propostos às idosas. 


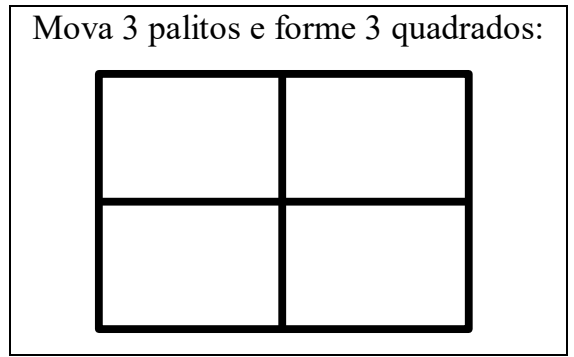

Quadro 3 - Um dos desafios propostos na atividade Desafio com Palitos Fonte: Os autores, com base em acervo do projeto Conversas Matemáticas (2018)

No desenvolvimento dessa atividade, as idosas começaram a questionar sobre as relações que poderiam ser estabelecidas entre o losango, o paralelogramo, o retângulo e o quadrado, fazendo com que as futuras professoras se deparassem com questionamentos em que não tinham pensado durante o planejamento da atividade:

Na montagem dos quadrados, Maria comentou "que o quadrado é um retângulo". Então a Lupércia, mencionou: "Mas não é o retângulo que é um quadrado?". Maria respondeu: "Não. Só o quadrado que é um retângulo". Assim, Alana comentou: "Você lembra, Maria, quando falamos desse assunto?", Maria disse que lembrava. Além disso, Maria perguntou se "o losango e o paralelogramo são um tipo de quadrado". Falamos para as idosas que iríamos confirmar e traríamos a resposta (Relatório confeccionado pelas bolsistas na atividade Desafio com Palitos, 2018).

Essa situação, que não foi discutida de imediato, levou as futuras professoras a refletirem, durante a reunião de planejamento subsequente ao encontro, e a elaborarem uma atividade que focasse nos pontos questionados pelas idosas. Isso foi feito na atividade Quadriláteros, que propôs às idosas a confecção dos quadriláteros quadrado, retângulo, paralelogramo e losango, para assim investigar quais as relações que poderiam ser estabelecidas entre estes quadriláteros.

Frente a essa situação, compreende-se que a zona de risco possibilitou o engajamento das futuras professoras na construção de uma nova atividade investigativa, de modo a criar oportunidades de aprendizagem, tanto para as idosas quanto para as próprias futuras professoras, que, até aquele momento, não haviam refletido sobre as relações apontadas entre os quadriláteros pelas idosas. Tal situação vai ao encontro do que Penteado e Skovsmose (2008) defendem, ao afirmarem que a zona de risco não deve ser encarada como uma situação problemática para a prática docente, mas como um momento oportuno para novas aprendizagens.

As experiências vivenciadas pelas futuras professoras com momentos imprevistos durante o desenvolvimento das atividades também colaboraram para que trabalhassem com sua imaginação pedagógica, que, segundo Milani (2017), corresponde à prática de imaginar possibilidades de ações que venham a acontecer, sendo criadas a partir do que se tem como 
situação real e influenciadas pela intenção das pessoas envolvidas na ação.

Eduarda, por exemplo, para tentar minimizar os momentos de imprevisibilidade que poderiam surgir no desenvolvimento das atividades, pensava em perguntas que as idosas pudessem fazer sobre os conteúdos matemáticos que seriam trabalhados e pesquisava buscando encontrar as soluções. Laura também destacou que, durante as reuniões de planejamento, sempre discutiam entre elas sobre situações que poderiam acontecer no desenvolvimento de uma atividade e colocá-las em uma zona de risco.

Algo que eu imaginava que elas [idosas] podiam perguntar. Eu sempre escrevia algumas definições, algo que poderia surgir sobre Matemática e sobre a atividade em si, questão da história, quem inventou, essas coisas, eu sempre buscava pesquisar sobre isso (Transcrição da entrevista com Eduarda, 2018).

Durante a preparação das atividades, a gente [bolsistas] já até pensava nos imprevistos, "olha, pode acontecer isso, nossa, mas pode surgir tal pergunta ali", então meio que a gente já preparava e já imaginava (Transcrição da entrevista com Laura, 2018).

Em nossa visão, antever os questionamentos que poderiam ser realizados pelas idosas está relacionado com o que Ball, Thames e Phelps (2008) chamam de conhecimento do conteúdo e do estudante, pois, ao conhecerem melhor o público com qual estavam trabalhando, as futuras professoras passaram a imaginar possíveis questionamentos das idosas participantes, com base no interesse de aprendizagem manifestado por elas.

Consideramos que as experiências vivenciadas pelas futuras professoras no projeto de extensão com a metodologia de ensino de investigação matemática e com as situações de zona de risco, favoreceram sua apropriação em utilizar esta metodologia de ensino em sua futura prática docente. Há diversas situações que demonstram tal apropriação. Por exemplo, durante as reuniões de planejamento da equipe do projeto, as futuras professoras discutiam sobre a postura do docente em uma atividade investigativa e, nessas conversas, também analisavam a própria prática de seus formadores no curso de Licenciatura em Matemática. Alana, por exemplo, argumentou sobre uma experiência com um de seus professores da graduação, relatando que ele poderia ter tido atitudes diferentes, caso utilizasse uma abordagem com abertura para investigação em sua prática. Ela apresentou reflexões sobre a importância do diálogo, tão característico em práticas pedagógicas pautadas na criação de cenários para investigação, na relação entre professor e estudante.

Alana relatou que, em uma reunião com o professor da graduação, ele lhe fez uma pergunta e ela respondeu, porém de forma incorreta. Ao invés dele voltar a pergunta para ela, o professor já lhe apresentou a resposta. Assim, Alana disse que ele deveria ter devolvido a pergunta, para que ela pensasse novamente na situação (Caderno de campo, 2018). 
Ponte, Brocardo e Oliveira (2006) defendem que o professor, em uma atividade investigativa, deve adotar uma postura interrogativa, como já mencionamos. Alana apontou que os questionamentos de seu professor do curso deveriam caminhar nesse sentido. Consideramos essa situação um indício de que ela compreendeu e se apropriou das ideias discutidas no projeto relacionadas ao trabalho com atividades investigativas.

Outra situação que indica uma apropriação dos procedimentos relacionados à metodologia de investigação matemática, em particular a criação de cenários para investigação em sala de aula, refere-se ao uso dos termos técnicos não somente nas entrevistas, mas também quando as licenciandas relatavam suas experiências ou quando escreviam os relatórios das atividades, como pode ser visto nos trechos destacados:

Alana também mencionou que, no momento em que uma das idosas perguntou sobre os tracinhos do amuleto, ela se sentiu em uma zona de risco por não saber respondê-la (Caderno de campo, 2018, grifo nosso).

Foi legal poder trabalhar fazendo diversas perguntas e investigando os quadrados mágicos. E perceber que elas tinham aceitado o convite. Para Alana as idosas aceitaram o convite devido ao fato de se empenharem na procura das respostas dos questionamentos (Relatório confeccionado pelas bolsistas na atividade Quadrados Mágicos, 2018, grifos nossos).

Tendo em vista tudo o que apontamos nesta seção, notamos que o projeto Conversas Matemáticas contribuiu para que as futuras professoras pudessem vivenciar novas experiências com a metodologia de ensino de investigação matemática; experienciar situações de proximidade entre a teoria estudada e a prática pedagógica; passar por experiências voltadas a conduzir atividades investigativas com uma postura aberta ao diálogo; caminhar por diferentes ambientes de aprendizagem durante o desenvolvimento das atividades com o público idoso; ter experiências positivas com as atividades investigativas, as quais favoreceram para a motivação em trabalhar com a investigação matemática e para o desenvolvimento de um sentimento de confiança em preparar e desenvolver atividades; bem como experienciar as potencialidades pedagógicas de situações de zona de risco.

Dessa forma, compreendemos que o envolvimento das futuras professoras no projeto de extensão e o seu trabalho pedagógico com o público idoso contribuíram em seu conhecimento pedagógico do conteúdo, uma vez que elas puderam aperfeiçoar o seu conhecimento sobre a metodologia de ensino de investigação matemática, o que favoreceu para que aprimorassem sua visão sobre como ensinar conteúdos matemáticos em sala de aula utilizando essa metodologia. De modo mais específico, notamos contribuições no conhecimento do conteúdo e do ensino, visto que as futuras professoras ampliaram o seu conhecimento em relação às metodologias de ensino, as quais consideramos importantes para 
o planejamento de uma atividade pedagógica. Avaliamos isso como uma consequência da própria estrutura do projeto, que, ao mesmo tempo em que oferecia suporte para as futuras professoras, também fornecia autonomia para que elas realizassem o planejamento e o desenvolvimento das atividades.

\section{Educação Matemática com pessoas idosas}

Trabalhar com o público idoso foi uma novidade para as futuras professoras, o que, consequentemente, demandou aprendizados sobre maneiras de lidar com o mesmo. Elas destacaram que, no decorrer do projeto, o contato que tiveram com as idosas participantes favoreceu a construção de um sentimento de amizade e de afeto entre elas. Reconheceram que isso contribuiu para que se sentissem seguras para desenvolver as atividades planejadas, vivenciassem experiências positivas no decorrer do projeto de extensão e construíssem uma boa relação com as idosas. Dessa forma, as experiências vivenciadas pelas futuras professoras em relação a tal sentimento colaboraram para sua compreensão sobre a importância de o professor construir uma boa relação com os seus estudantes. Eduarda, por exemplo, demonstra tal aprendizado em uma de suas reflexões:

Acho que a importância de estabelecer a boa relação com os alunos, eu acho que isso fez o projeto dar muito certo também, a questão de a gente gostar muito delas [idosas] e delas gostarem muito da gente. Acho que isso é importante, ter uma boa relação (Transcrição da entrevista com Eduarda, 2018).

Consideramos que a compreensão adquirida pelas futuras professoras poderá ser de grande relevância para sua futura prática docente, pois, ao atuarem em sala de aula, terão conhecimento da importância de o professor construir uma boa relação com os seus estudantes, fato que, segundo Silva e Mamedio (2016), contribui positivamente para a aprendizagem destes últimos.

As futuras professoras já tinham experiência em trabalhar com estudantes da Educação Básica. Por meio do projeto de extensão, elas estavam vivenciando novas experiências, principalmente pelo fato de trabalharem com o público idoso. Isso fez com que pudessem refletir sobre diferenças entre as idosas do projeto e os estudantes da Educação Básica, com os quais haviam trabalhado.

Entre as diferenças apontadas, a mais comentada diz respeito ao perfil de cada um dos públicos, pois as futuras professoras destacaram que, enquanto as idosas eram críticas e questionadoras, os estudantes da Educação Básica já possuíam um perfil oposto. Por exemplo, Eduarda, durante a entrevista, destacou tal diferença ressaltando a dificuldade que tinha em 
fazer com que os estudantes da Educação Básica se envolvessem nas atividades, algo que não era problema durante o projeto Conversas Matemáticas:

Acho que as dificuldades eram ao contrário, né, tipo na sala de aula a dificuldade era fazer os alunos falarem, eles não perguntavam nada, não respondiam nada e não davam nenhuma resposta para a gente sobre a atividade. Não relacionavam nada com nada. E aqui [no projeto de extensão] a dificuldade no caso inicial, em algumas vezes, era justamente a questão da curiosidade, o tanto de pergunta que tinha. Talvez uma dificuldade seja a questão de risco mesmo, no sentido das perguntas, principalmente no começo [do projeto de extensão] (Transcrição da entrevista com Eduarda, 2018).

A comparação entre os dois públicos, destacada pelas futuras professoras, revela indícios de que a postura ativa e crítica das idosas durante o desenvolvimento das atividades matemáticas foi importante para que as futuras professoras pudessem vivenciar situações em que as participantes aceitaram o convite para entrarem em cenários para investigação. Para nós, os comentários de comparação feitos por elas, em relação ao modo ativo de se envolver das idosas nas atividades do projeto e as atitudes passivas dos estudantes da Educação Básica com os quais elas haviam trabalhado, podem contribuir para que sua prática docente seja direcionada a estimular seus estudantes a participarem ativamente das atividades desenvolvidas, realizando questionamentos, comentários e investigações sobre o assunto estudado, uma vez que puderam vivenciar os avanços pedagógicos que isso traz aos envolvidos.

Outra reflexão importante que pode ter favorecido a formação das futuras professoras diz respeito à oportunidade de trabalhar com idosas com diferentes perfis e características. Nos dois primeiros meses do projeto, as atividades eram desenvolvidas em dois dias da semana, às terças e quartas-feiras. Às terças-feiras, participavam as idosas Magda, Márcia, Mariana e Matilde ${ }^{2}$. Às quartas-feiras, participavam as senhoras Ângela, Aparecida, Carla, Cláudia, Cleuza, Larissa, Lupércia, Maria, Paula e Sílvia ${ }^{3}$. O trabalho desenvolvido com os dois grupos de idosas fez com que as futuras professoras tivessem que lidar com diferentes públicos:

Um dos pontos levantados pelas estudantes é o fato de precisar lidar com públicos diferentes, pois as idosas que participam na quarta-feira se empenham mais nas atividades e na terçafeira elas não interagem, e a Magda sempre menciona estar cansada, isso acaba atrapalhando (Caderno de campo, 2018).

As estudantes estão aprendendo a lidar com diferentes públicos, visto que na terça-feira as idosas não interagem muito e não realizam muitas perguntas, diferentemente do que ocorre

\footnotetext{
${ }^{2}$ Nomes fictícios.

${ }^{3}$ Nomes fictícios.
} 
com a turma da quarta-feira (Relatório confeccionado pelas bolsistas na atividade Quadrados Mágicos, 2018).

Os trechos destacados evidenciam que, enquanto na quarta-feira o grupo de idosas participava ativamente das atividades, demonstrando empenho em desenvolvê-las, na terçafeira o outro grupo de idosas já não indicava o mesmo desempenho. Frente à diferença estabelecida, pode-se considerar que o projeto de extensão propiciou às futuras professoras a oportunidade de desenvolver uma mesma atividade matemática com diferentes públicos, o que consequentemente exigiu diferentes formas de lidar com cada um dos grupos de idosas. Enquanto na terça-feira as futuras professoras precisavam incentivar as idosas e insistir para que elas desenvolvessem as atividades, na quarta-feira já não era necessário, pois a motivação para desenvolver as atividades era algo que surgia das próprias participantes.

Essa experiência vivenciada pelas bolsistas está próxima da situação que Tardif (2012) destaca que ocorre durante a carreira docente. $\mathrm{O}$ autor aponta que professores e professoras, ao exercerem sua profissão, geralmente precisam trabalhar com diversas séries/anos de ensino, o que consequentemente faz com que tenham de desenvolver seu trabalho pedagógico com públicos distintos (crianças, adolescentes, jovens e adultos), exigindo diferentes maneiras de agir com cada um dos públicos.

Compreendemos que o projeto Conversas Matemáticas foi uma oportunidade para que as futuras professoras se familiarizassem com o trabalho pedagógico desenvolvido com diferentes públicos, situação que professores e professoras vivenciam em sua carreira, pois, além de atuarem em diferentes séries/anos, também podem lecionar em uma mesma série/ano, mas em diferentes turmas.

Ademais, consideramos que as experiências vivenciadas pelas futuras professoras durante o desenvolvimento de atividades matemáticas com o público idoso propiciaram a elas um novo significado para a Educação Matemática. Sobre essa questão, Laura destacou que:

Dentro da experiência profissional, eu vi a Matemática de outra forma, a experiência foi outra, porque en estava acostumada a ficar ali dentro da sala de aula. Então, na hora que eu saí, eu vi a possibilidade de como a Matemática poderia ajudar as pessoas [idosas], mesmo em outra fase da vida. Além de ter sido gratificante em ajudá-las, foi outra experiência, completamente diferente. Porque, igual eu falei, é outra Matemática, é a Matemática, mas é outra Matemática. Não é aquela Matemática dentro da sala de aula, muitas vezes dentro da sala de aula a gente impõe muitas regras, muito é isso, é aquilo, você tem que fazer isso, você tem que ir por esse caminho. Por mais que a gente queira fazer os alunos pensarem, sem a gente ver, a gente impõe aquilo para os alunos, "oh, você tem que fazer isso". Ali [no projeto de extensão] não, ali é uma coisa que flui naturalmente, a gente levava as coisas para elas [idosas], elas nos voltavam com outras coisas, a gente usava o que elas nos voltavam. Então a gente moldava com aquilo que elas, não sei explicar, aquilo que elas voltavam para a gente, a gente tentava moldar e levava uma outra atividade para elas. Havia uma troca ali, dentro da sala de aula infelizmente não é essa troca, infelizmente muitas vezes, com a correria, por ter 
que cumprir ementa, não há muito uma troca entre aluno e professor (Transcrição da entrevista com Laura, 2018).

Este novo significado para a Educação Matemática está relacionado ao apontamento de ver a Matemática de outra forma e a possibilidade de um trabalho educativo em que o professor deixa de ser o centro da atividade profissional e se coloca em posição de troca, utilizando o que os estudantes levam para a sala de aula. De modo específico, sobre o trabalho pedagógico com o público idoso e com base nas leituras e discussões realizadas sobre a pesquisa de Lima (2015), consideramos que Laura ampliou sua visão em relação à Educação Matemática, ao considerar a Matemática como um meio para ajudar as pessoas tanto no desenvolvimento de capacidades cognitivas quanto na inclusão social de diferentes grupos.

Compreender a Educação Matemática como um meio para o estímulo do desenvolvimento de capacidades cognitivas de pessoas idosas vai ao encontro do que apontam Lima, Penteado e Silva (2019). Os autores destacam que a realização de atividades matemáticas com pessoas idosas melhora os aspectos cognitivos deste público, pois favorece o desenvolvimento do raciocínio lógico, a capacidade de observação e de atenção e o estímulo à concentração. Além disso, entender a Educação Matemática como um meio de inclusão social dos idosos vai na direção do que apontam Julio e Silva (2019b). Estes autores analisaram o próprio projeto Conversas Matemáticas, mas com um olhar nas contribuições para a inclusão social das idosas participantes. Apontam que o projeto contribuiu para que as idosas aprendessem sobre assuntos matemáticos, o que colaborou para que elas se incluíssem em um ambiente social, compartilhando seus conhecimentos com familiares e amigos. Em vários momentos do projeto, as futuras professoras se depararam com as idosas comentando sobre os momentos que tiveram com suas famílias ao desenvolver as atividades matemáticas que aprenderam no projeto (trecho destacado a seguir). Consideramos que a vivência de experiências nesse sentido pode ter contribuído para que as futuras professoras produzissem outro significado para a Educação Matemática, relacionado com algo para além do ensino e da aprendizagem, mas como um veículo de inclusão social das idosas participantes.

Antes de iniciar a atividade Sequência de Fibonacci, Maria comentou que compartilhou o jogo Dominó das Quatro Cores com sua família e que eles fizeram uma competição. $O$ seu neto foi o primeiro a conseguir montar e também fotografou mostrando aos demais que havia conseguido (Relatório confeccionado pelas bolsistas na atividade Sequência de Fibonacci, 2018).

Lima (2015) aponta que, ao desenvolver atividades pedagógicas com o público idoso, é essencial buscar proporcionar experiências prazerosas com a Matemática. Frente a esta recomendação, as futuras professoras sempre buscaram planejar atividades que pudessem 
propiciar às idosas novas experiências com a Matemática, tentando diversificá-las com base em diferentes gostos pessoais das idosas, como interesses em temas históricos e artísticos, em jogos e em materiais manipulativos.

Dessa forma, foram elaboradas e desenvolvidas diversas delas, como, por exemplo, atividades que exploraram conceitos geométricos por meio da construção de origamis, que trabalharam com o conceito de reflexão e figuras geométricas por meio do Tangram, que exploraram frações através da Barra de Cuisenaire, que discutiram sobre quadriláteros por meio de práticas de construção, que exploraram o conceito de função exponencial por meio da Torre de Hanói, que trabalharam com operações básicas utilizando o jogo Contig 60, entre outras atividades. Como consequência, as atividades matemáticas realizadas no projeto contribuíram para que as futuras professoras ampliassem sua visão sobre maneiras de desenvolver atividades e de discutir sobre conteúdos matemáticos, como pode ser visto no trecho a seguir:

Acho que eu não poderia me formar sem ter passado por aqui. Porque eu acho que mudou muita coisa na minha vida. A visão mesmo da própria Matemática. (...) Eu entrei no PIBID, e eu tive muitas experiências lá também, umas me marcaram e outras nem tanto. Eu lembro que, na primeira aula que eu ministrei, eu saí falando que não voltaria ali nunca mais. Nossa, dá muita vontade. E ter a oportunidade de passar por aqui [no projeto de extensão] me fez mudar minha visão mesmo, porque me fez ver que há outras formas de trabalhar a Matemática (Transcrição da fala de Laura na atividade dinâmica de autoavaliação, 2018).

A fala de Laura nos remete ao entendimento de que sua visão sobre o ensino de Matemática poderia estar pautada no paradigma do exercício, em que o professor expõe o conteúdo e propõe um conjunto de exercícios aos estudantes. O que compreendemos, por meio de sua fala, é que o projeto de extensão propiciou oportunidades para se envolver em práticas e experiências com os conteúdos matemáticos trabalhados de diferentes formas.

Para nós, essas experiências contribuíram com o conhecimento pedagógico do conteúdo das futuras professoras, pois elas ampliaram seu repertório de trabalho pedagógico, ou seja, conheceram e desenvolveram diferentes atividades matemáticas, as quais poderão utilizar em sala de aula no ensino de determinados conteúdos matemáticos. Também consideramos que o desenvolvimento das diversas atividades matemáticas colaborou para que as futuras professoras aperfeiçoassem o seu repertório de conhecimento do conteúdo e do estudante, devido a se colocarem na posição de desenvolver atividades que pudessem ser consideradas interessantes para as idosas, ou seja, atividades que levassem em consideração os diferentes gostos pessoais das participantes. Além disso, as futuras professoras tiveram experiências enriquecedoras no trabalho com o público idoso, algo que dificilmente teriam vivenciado durante as disciplinas de graduação ou mesmo no estágio supervisionado. 


\section{Considerações finais}

Buscamos neste trabalho compreender as contribuições para a formação inicial de professores de Matemática quando envolvidos em um projeto de extensão universitária, direcionado ao público idoso. Conforme discutimos ao longo do artigo, temos indícios de que o envolvimento das futuras professoras no projeto de extensão Conversas Matemáticas propiciou diversas contribuições para sua formação. Destacamos tais indícios em duas categorias de análise: investigação matemática enquanto metodologia de ensino e Educação Matemática com pessoas idosas.

$\mathrm{Na}$ primeira categoria, apresentamos discussões que indicaram contribuições para o conhecimento pedagógico do conteúdo das futuras professoras, uma vez que elas aperfeiçoaram o seu conhecimento em relação à metodologia de ensino de investigação matemática, em especial à criação de cenários para investigação, o que colaborou para que elas ampliassem sua concepção sobre como ensinar conteúdos matemáticos utilizando esta metodologia. Também apontamos contribuições propiciadas em seu conhecimento do conteúdo e do ensino, pois ampliaram o seu repertório de metodologias de ensino, as quais se referem a um dos elementos a serem selecionados no planejamento de uma atividade.

$\mathrm{Na}$ segunda categoria, também destacamos indícios de contribuições para o conhecimento pedagógico do conteúdo das futuras professoras, pois elas tiveram a oportunidade de conhecer e explorar diversas atividades matemáticas, as quais poderão ser adaptadas e utilizadas em sua futura prática docente. Também apresentamos contribuições para a formação das futuras professoras envolvidas no projeto que ultrapassam os conhecimentos que Shulman (2014) e Mizukami (2004) destacam serem necessários para a prática docente, uma vez que as futuras professoras compreenderam a importância de o professor construir uma boa relação com os seus estudantes, vivenciaram experiências que lhes demonstraram a relevância de estimular os estudantes a serem sujeitos ativos no desenvolvimento de uma atividade, se familiarizaram com o trabalho pedagógico desenvolvido com um público com diferentes características e ampliaram sua visão sobre a Educação Matemática.

Em relação às contribuições destacadas, compreendemos que a participação das futuras professoras de Matemática no projeto colaborou para que elas complementassem sua formação durante a Licenciatura em Matemática. Nesse sentido, entendemos ser de grande relevância atender à demanda da Resolução CNE/CES n 7 , de 2018, referente a destinar, no mínimo, dez por cento do total de créditos exigidos em cursos de graduação a que sejam 
cumpridos por meio de programas e projetos de extensão universitária (BRASIL, 2018).

Para nós, atender a esta resolução poderá favorecer que todos os futuros professores e professoras tenham a oportunidade de participar de programas ou projetos de extensão, o que, consequentemente, poderá contribuir para que todos possam, durante seu processo formativo, construir conhecimentos que ampliem a sua formação. Para finalizar, consideramos que este estudo abre possibilidades para a formação de professores de Matemática, por meio de um trabalho com o público idoso, uma vez que vislumbramos essa temática como um novo campo de pesquisa em Educação Matemática e acreditamos que mais estudos possam ser desenvolvidos, buscando ampliar as discussões que foram realizadas neste artigo.

\section{Referências}

ALRØ, H.; SKOVSMOSE, O. Diálogo e Aprendizagem em Educação Matemática. 2. ed. Belo Horizonte: Autêntica, 2010.

ALVES, L. L. Implicações do PIBID na formação inicial de professores de Matemática. Crítica Educativa, Sorocaba, v. 3, n. 2, p. 591-601, jan./jun. 2017.

BALL, D. L.; THAMES, M. H.; PHELPS, G. Content knowledge for Teaching: What Makes it Special? Journal of Teacher Education, New York, v. 59, n. 5, p. 389-407, nov./dez. 2008.

BARBOSA, G. S. Extensão Universitária: contribuições de professores guarani para a formação inicial de professores de Matemática. Espaço Pedagógico, Passo Fundo, v. 25, n. 3, p. 777-800, set./dez. 2018.

BARBOSA, J. G.; LOPES, C. E. Desafios e particularidades narrados pelos docentes da Licenciatura em Matemática do Instituto Federal de Minas Gerais. Educação Matemática Pesquisa, São Paulo, v. 21, n. 1, p. 477-495, 2019.

BARDIN, L. Análise de Conteúdo. Tradução de Luis Antero Reto e Augusto Pinheiro. 1. ed., 3. reimpr., rev. e ampl. São Paulo: Edições 70, 2016.

BRASIL. Resolução $n^{\circ}$ CNE/CP 2, de 1 de julho de 2015. Define as Diretrizes Curriculares Nacionais para a formação inicial em nível superior (cursos de licenciatura, cursos de formação pedagógica para graduados e cursos de segunda licenciatura) e para a formação continuada. Diário Oficial da União, Brasília, 2 de julho de 2015, seção 1, p. 8-12.

BRASIL. Resolução $n^{\circ}$ CNE/CES 7, de 18 de dezembro de 2018. Estabelece as Diretrizes para a Extensão na Educação Superior Brasileira e regimenta o disposto na Meta 12.7 da Lei n ${ }^{\circ}$ 13.005/2014, que aprova o Plano Nacional de Educação - PNE 2014 - 2024 e dá outras providências. Diário Oficial da União, Brasília, 19 de dezembro de 2018, seção 1, p. 49.

CRESWELL, J. W. Investigação Qualitativa e Projeto de Pesquisa: escolhendo entre cinco abordagens. 3. ed. Porto Alegre: Penso, 2014.

ELIAS, H. R.; SAVIOLI, A. M. P. D.; RIBEIRO, A. J. Números racionais e estrutura algébrica corpo: problematizando o currículo da formação inicial de professores de Matemática. Educação

Matemática Pesquisa, São Paulo, v. 19, n. 3, p. 182-208, 2017. 
FONSECA, V.; HENRIQUES, A. Compreensão da definição formal de limite: um estudo na formação inicial de professores de Matemática. Bolema, Rio Claro, v. 32, n. 62, p. 1030-1049, dez. 2018.

JULIO, R. S.; SILVA, G. H. G. O projeto Conversas Matemáticas e a pessoa idosa: uma proposta pedagógica multifacetada. In: ENCONTRO NACIONAL DE EDUCAÇÃO MATEMÁTICA, 13. 2019a, Cuiabá. Anais[...] Cuiabá: Universidade do Estado de Mato Grosso, 2019a. p. 3-12.

JULIO, R. S.; SILVA, G. H. G. Educação Matemática, inclusão social e pessoas idosas: uma análise do projeto Conversas Matemáticas no âmbito do Programa Universidade Aberta à Pessoa Idosa.

Educação Matemática em Revista, Brasília, v. 24, n. 64, p. 52-70, 2019 b.

LIMA, L. F. Conversas sobre Matemática com pessoas idosas viabilizadas por uma ação de Extensão Universitária. 2015. Tese (Doutorado em Educação Matemática) - Instituto de Geociências e Ciências Exatas, Universidade Estadual Paulista, Rio Claro, 2015.

LIMA, L. F.; PENTEADO, M. G.; SILVA, G. H. G. Há sempre o que ensinar, há sempre o que aprender: como e por que Educação Matemática na terceira idade? Bolema, Rio Claro, v. 33, n. 65, p. 1331-1356, 2019.

LOPES, E. P.; COSTA, W. N. G. Contribuições da Extensão Universitária à formação docente. In: ENCONTRO NACIONAL DE EDUCAÇÃO MATEMÁTICA, 12., 2016, São Paulo. Anais[...] São Paulo: Universidade Cruzeiro do Sul, 2016. p. 1-10.

LUDKE, M.; ANDRÉ, M. E. D. A. A pesquisa em Educação: abordagens qualitativas. São Paulo: EPU, 1986.

MANDLER, M. L.; MUNHOZ, R. H.; AZEVEDO, E. B.; MORO, G. As contribuições de um projeto de extensão na formação inicial do professor de Matemática. Revista +E versión digital, Santa Fé, v. 6, p. 330-335, 2016.

MILANI, R. "Sim, eu ouvi o que eles disseram": o diálogo como movimento de ir até onde o outro está. Bolema, Rio Claro, v. 31, n. 57, p. 35-52, abr. 2017.

MIZUKAMI, M. G. N. Aprendizagem da docência: algumas contribuições de L. S. Shulman. Revista Educação, Santa Maria, v. 29, n. 2, p. 33-49, 2004.

OLIVEIRA, A. T. C. C.; FIORENTINI, D. O papel e o lugar da didática específica na formação inicial do professor de Matemática. Revista Brasileira de Educação, Rio de Janeiro, v. 23, p. 1-17, 2018.

PENTEADO, M. G. Computer-based learning environments: risks and uncertainties for teacher. Ways of Knowing Journal, Brighton, v. 1, n. 2, p. 23-35, 2001.

PENTEADO, M. G.; SKOVSMOSE, O. Riscos trazem possibilidades. In: SKOVSMOSE, O. (Org.). Desafios da reflexão em Educação Matemática Crítica. Campinas: Papirus, 2008. p. 41-50.

PONTE, J. P. Investigação sobre investigações matemáticas em Portugal. Investigar em Educação, Lisboa, v. 2, p. 93-169, 2003.

PONTE, J. P.; BROCARDO, J.; OLIVEIRA, H. Investigações matemáticas na sala de aula. Belo Horizonte: Autêntica, 2006.

RIBEIRO, R. M. Modelagem Matemática e mobilização de conhecimentos didático-matemáticos na formação continuada de professores dos anos iniciais. 2016. Tese (Doutorado em Educação) Programa de Pós-Graduação em Educação, Universidade Federal de São Carlos, São Carlos, 2016. 
ROSA, F. M. C. Professores de Matemática e a educação inclusiva: análises de memórias de formação. 2013. Dissertação (Mestrado em Educação Matemática) - Universidade Estadual Paulista, Instituto de Geociências e Ciências Exatas, Rio Claro, 2013.

SHULMAN, L. S. Conhecimento e ensino: fundamentos para a nova reforma. Tradução de Leda Back e revisão técnica de Paulo Louzano. Cadernoscenpec, São Paulo, v. 4, n. 2, p. 196-229, dez. 2014.

SILVA, A. M. C.; PENHA, N. R.; GONÇALVES, J. P. Extensão Universitária e formação docente: contribuições de um projeto de extensão para estudantes de pedagogia. Revista formação@docente, Belo Horizonte, v. 9, n. 1, p. 74-86, jan./jun. 2017.

SILVA, D.; MAMEDIO, M. P. A relação professor x aluno para o ensino aprendizagem. In: CONGRESSO DE INICIAÇÃO CIENTÍFICA, ESTÁGIO E DOCÊNCIA DO CAMPUS FORMOSA, 2016, Formosa. Anais [...] Formosa: Universidade Estadual de Goiás, 2016. p. 1-10.

SILVA, G. H. G.; PENTEADO, M. G. Geometria dinâmica na sala de aula: o desenvolvimento do futuro professor de Matemática diante da imprevisibilidade. Ciência \& Educação, Bauru, v. 19, n. 2, p. 279-292. 2013.

SKOVSMOSE, O. Cenários para investigação. Bolema, Rio Claro, v. 13, n. 14, p. 1-24. 2000.

SKOVSMOSE, O. Um convite à Educação Matemática Crítica. Campinas: Papirus, 2014.

SOUZA, K. C. P. Formação inicial do professor de Matemática com uso de tecnologias da informação e comunicação no contexto da escola pública. 2016. Dissertação (Mestrado Profissional) - Programa de Mestrado em Ensino de Ciências e Matemática, Universidade Federal de Uberlândia, Uberlândia, 2016.

TARDIF, M. Saberes docentes e formação profissional. 14. ed. Petrópolis: Vozes, 2012.

TEIXEIRA, B. R.; CYRINO, M. C. C. T. Desenvolvimento da identidade profissional de futuros professores de Matemática no âmbito da orientação de estágio. Bolema, Rio Claro, v. 29, n. 52, p. 658-680, ago. 2015.

ZABEL, M.; MALHEIROS, A. P. S. Prática como Componente Curricular: entendimentos, possibilidades e perspectivas. Educação Matemática Pesquisa, São Paulo, v. 20, n. 1, p. 128-146, 2018. 